\title{
Bacterial communities of herbivores and pollinators that have co-evolved Cucurbita spp.
}

5 Lori R. Shapiro ${ }^{1,2}$, Madison Youngblom ${ }^{3}$, Erin D. Scully ${ }^{4}$, Jorge Rocha ${ }^{5}$, Joseph Nathaniel

6 Paulson $^{6}$, Vanja Klepac-Ceraj ${ }^{7}$, Angélica Cibrián-Jaramillo ${ }^{8}$, Margarita M. López-Uribe ${ }^{9}$

$8{ }^{1}$ Department of Applied Ecology, North Carolina State University, Raleigh, NC, 27695 USA

$9{ }^{2}$ Department of Organismic and Evolutionary Biology, Harvard University, Cambridge MA,

$10 \quad$ USA 02138

$11{ }^{3}$ Department of Medical Microbiology \& Immunology, University of Wisconsin-Madison,

12 Madison WI, 53706 USA

$13{ }^{4}$ Center for Grain and Animal Health Research, Stored Product Insect and Engineering Research

14 Unit, USDA-Agricultural Research Service, Manhattan, KS, 66502 USA

$15{ }^{5}$ Conacyt-Centro de Investigación y Desarrollo en Agrobiotecnología Alimentaria, San Agustin

16 Tlaxiaca, Mexico 42162

$17{ }^{6}$ Department of Biostatistics, Product Development, Genentech Inc., South San Francisco,

18 California 94102

$19{ }^{7}$ Department of Biological Sciences, Wellesley College, Wellesley, MA 02481 USA 16803

$20{ }^{8}$ Laboratorio Nacional de Genómica para la Biodiversidad, Centro de Investigación y de

21 Estudios Avanzados del IPN, Irapuato, Mexico 36284

$22{ }^{9}$ Department of Entomology, Center for Pollinator Research, Pennsylvania State University,

23 University Park, PA 
25 Author Contributions: LRS conceived of the study; LRS, MY, JR designed and conducted the

26 laboratory work; LRS, MY, ES, JR, JNP, ACJ, MMLU interpreted data; LRS wrote the first

27 version of the manuscript and LRS, MY, ES, JR, JNP, ACJ, MMLU critically revised the

28 manuscript.

30 Data Deposition Statement: Raw sequencing data generated for this study are deposited at

31 NCBI SRA accession SUB5883192, and processed OTUs are deposited at SUB5883184. All

32 processing and analysis scripts are available at https://github.com/lshapiro31/insect.microbiome

\section{Abstract}

35 Insects, like all animals, are exposed to diverse environmental microbes throughout their life cycle. Yet, we know little about variation in the microbial communities associated with the

37 majority of wild, unmanaged insect species. Here, we use a 16S rRNA gene metabarcoding

38 approach to characterize temporal and geographic variation in the gut bacterial communities of

39 herbivores (Acalymma vittatum and A. trivittatum) and pollinators (Eucera (Peponapis)

40 pruinosa) that have co-evolved with the plant genus Cucurbita (pumpkin, squash, zucchini and

41 gourds). Overall, we find high variability in the composition of bacterial communities in squash

42 bees and beetles collected from different geographic locations and different time points

43 throughout a growing season. Still, many of the most common OTUs are shared in E. (P.)

44 pruinosa, A. vittatum and A. trivittatum. This suggests these insects may be exposed to similar

45 environmental microbial sources while foraging on the same genus of host plants, and that

46 similar microbial taxa may aid in digestion of Cucurbita plant material. The striped cucumber

47 beetle A. vittatum can also transmit Erwinia tracheiphila, the causal agent of bacterial wilt of 
48 cucurbits. We find that few field-collected $A$. vittatum individuals have detectable $E$.

49 tracheiphila, and when this plant pathogen is detected, it comprises less than $1 \%$ of the gut

50 bacterial community. Together, these results are consistent with previous studies showing that

51 plant feeding insects have highly variable gut bacterial communities, and provides a first step

52 towards understanding the spatiotemporal variation in the microbial communities associated with

53 herbivores and pollinators that depend on Cucurbita host plants.

56 Keywords: Cucurbita, Erwinia tracheiphila, Eucera, Peponapis, Acalymma, bacterial wilt

57 disease, microbiome, pollination ecology, squash bee, striped cucumber beetle, plant pathoge 


\section{Introduction}

59 Herbivorous insects that consume leaf, floral, stem or root tissues are exposed to diverse communities of microbes associated with plants and/or soil. Many microbes ingested by insects

61 likely pass transiently through the digestive tract and may not confer any impact on the host

62 insect (Oliver et al. 2008, Hammer et al. 2017, Hammer et al. 2019). However, some microbes

63 are able to colonize insects as hosts, and can have diverse and consequential - yet often cryptic -

64 roles in mediating ecological interactions between plants, other insects and other microbes

65 (Shapiro et al. 2012, Chung et al. 2013, Shapiro et al. 2013, Wang et al. 2016, Mason et al.

66 2018). For example, many pollinators likely transfer microbes between flowers during normal

67 foraging that may directly affect other visiting insects, or indirectly alter traits determining floral

68 attractiveness (Yang et al. , McArt et al. 2014, Ravoet et al. 2014, Vannette and Fukami 2016,

69 Rering et al. 2018, Figueroa et al. 2019). Some insect pollinators and herbivores encounter plant

70 pathogens while feeding, and can then transmit these pathogens from infected to healthy plants

71 (Raguso and Roy 1998, Alexandrova et al. 2002, López-Villavicencio et al. 2007, Degnan et al.

72 2009, Shapiro et al. 2012, Shapiro et al. 2014, Mauck et al. 2018, Shapiro and Mauck 2018,

73 Cellini et al. 2019). Yet, for almost all insect taxa, we still lack an understanding of the spatial

74 and temporal diversity of microbes that insects are naturally exposed to, which microbes are able

75 to persistently colonize insects as hosts vs. transiently pass through the digestive tract, and the

76 impacts of different microbes on ecological interactions.

77 The pollinators and herbivores that have co-evolved with the plant genus Cucurbita

78 (Cucurbitaceae) are an ideal system to investigate how a shared host plant affects microbiome

79 composition for insect species that have different life histories and ecological functions.

80 Cucurbita (zucchini, squash, pumpkin, and some yellow-flowered gourds) is comprised of 14 
81 closely related species that are native to the New World tropics and subtropics (Whitaker and

82 Bemis 1975, Metcalf and Lampman 1989, Kates et al. 2017, Castellanos-Morales et al. 2018).

83 All bee species in the genus Eucera and sub-genera Peponapis and Xenoglossa (Hymenoptera:

84 Anthophila: Apidae: Eucerini: Eucera) - commonly known as squash bees - are obligate

85 specialists of Cucurbita pollen (Baker and Hurd Jr 1968, Hurd et al. 1971, Hurd et al. 1974). The

86 emergence of squash bees in the summer coincides with the Cucurbita bloom period, and these

87 ground-nesting, solitary bees exclusively use pollen from Cucurbita flowers to feed their brood

88 (Hurd and Linsley 1964, Hurd and Linsley 1967, Hurd et al. 1971, Hurd et al. 1974). Acalymma

89 (Barber) leaf beetle herbivores (Coleoptera: Chrysomelidae: Luperini: Diabriticina) have also co-

90 evolved with Cucurbita, and all $\sim 70$ species of Acalymma are obligately dependent on Cucurbita

91 in all life stages. Acalymma larvae are rootworms, and adults feed on above-ground leaves,

92 flowers and fruits (Barber 1946, Metcalf et al. 1980, Munroe and Smith 1980, Ferguson and

93 Metcalf 1985, Ferguson et al. 1985, Tallamy and Krischik 1989, Tallamy and Gorski 1997,

94 Tallamy et al. 1997, Kistler et al. 2015).

95 The squash bee (Eucera (P.) pruinosa) and the striped cucumber beetle (Acalymma

96 vittatum) are the two most common Cucurbita-associated insects in temperate Eastern North

97 America. E. pruinosa has recently expanded its geographic range into this region by following

98 the human-mediated dispersal of domesticated Cucurbita pepo from the subtropical Eastern

99 United States (Petersen and Sidell 1996, Monaghan et al. 2006, Smith 2006, López-Uribe et al.

100 2016), and it is likely that $A$. vittatum has a similar demographic history. In temperate Eastern

101 North America, both E. pruinosa and A. vittatum exclusively rely on domesticated plants grown

102 in human managed agro-ecosystems as a food resource. Temperate Eastern North America is

103 also the only region worldwide where A. vittatum transmits Erwinia tracheiphila Smith 
104 (Enterobacteriaceae), the causal agent of bacterial wilt of cucurbits, which causes millions of

105 dollars annually in direct yield losses and indirect preventative measures (Shapiro et al. 2014,

106 Shapiro et al. 2016, Shapiro et al. 2018b). E. tracheiphila can persistently colonize the digestive

107 tract of beetle vectors after beetles feed on the foliage of wilting, symptomatic plants (Rand and

108 Enlows 1916, Rand and Cash 1920, Rand and Enlows 1920, Smith 1920, Shapiro et al. 2012,

109 Shapiro et al. 2014). However, dynamics of vector colonization by E. tracheiphila in the field,

110 and potential interactions with other microbes in the beetle's digestive tract remain almost

111 completely unknown (Fleischer et al. 1999, Shapiro et al. 2014).

112 Here, we use $16 \mathrm{~S}$ rRNA gene barcode sequencing to describe variation in the bacterial

113 communities of the squash bee Eucera (P.) pruinosa, and the striped cucumber beetles

114 Acalymma vittatum and A. trivittatum. Insects were field-collected from their native range in the

115 United States Southwest and in Central Mexico, and from their introduced range in temperate

116 North America. We find high overall variation in bacterial community composition within and

117 between beetles and bees that specialize on Cucurbita, but substantial overlap in the most

118 common bacterial OTUs. We also find that few Acalymma beetles are colonized by detectable

119 Erwinia tracheiphila, and that OTUs that are the closest match to E. tracheiphila are a minor

120 component of the beetle vector's gut bacterial community. Together, these results suggest the

121 shared Cucurbita host plants are likely a strong factor influencing microbial community

122 composition of bees and beetles that have co-evolved with these hosts.

\section{Methods}

125 The study system 
127 al. 2017). All are fast-growing vines, and many wild species are common throughout the New

128 World tropics and subtropics (Kates et al. 2017, Castellanos-Morales et al. 2018). All Cucurbita

129 produce large, yellow, sweetly scented flowers that only open a single morning from sunrise

130 until midday, and then dehisce. Flowers release a blend of volatile organic compounds that act as

131 long distance host location cues for co-evolved pollinators and herbivores. Cucurbita also

132 produce a group of oxygenated tetracyclic tri-terpenes called 'cucurbitacins' that are among the

133 most bitter compounds known, with broad-spectrum toxicity against almost all insect and

134 mammalian herbivores (David and Vallance 1955, Fraenkel 1959, Whitaker and Bemis 1964,

135 Chambliss and Jones 1966, Shang et al. 2014, Zhou et al. 2016). For Diabroticite leaf beetle

136 herbivores (Coleoptera: Chrysomelidae: Luperini: Diabroticina), cucurbitacins are arrestants and

137 feeding stimulants. All Acalymma are specialists on Cucurbita in all life stages, while Diabrotica

138 and Ceratoma spp. only visit Cucurbita pharmacophagically as adults to sequester cucurbitacins

139 (Metcalf et al. 1980, Tallamy and Krischik 1989, Dinan et al. 1997, Tallamy et al. 1997, Tallamy

140 1998). Acalymma larvae feed underground on Cucurbita roots, and adults feed on leaves, flowers

141 and fruits (Barber 1946, Munroe and Smith 1980, Tallamy 1999, Eben and Espinosa 2013,

142 Shapiro and Mauck 2018).

143 While insect herbivory has driven the evolution of Cucurbita functional traits over their

144 millions of years of co-evolutionary history, humans have shaped the more recent evolution of

145 many Cucurbita species. Cucurbita pepo was the first plant domesticated for agriculture in the

146 Americas, and Cucurbita moschata was the second (Smith 1993, Smith 1997, Piperno and

147 Stothert 2003, Smith 2006). As the glaciers retreated during the Holocene around 5,000 years

148 ago, cultivated Cucurbita were the first crop plant introduced into temperate Eastern North 
America by humans for agriculture from a second independent domestication of Cucurbita pepo

150 in the Mississippi River Valley (Petersen and Sidell 1996, Monaghan et al. 2006, Smith 2006). It

151 is likely that movement of domesticated Cucurbita pepo varieties into temperate Eastern North

152 America had profound - but still largely unknown - impacts on the biotic community that had

153 co-evolved with Cucurbita for millions of years. Eucera (P.) pruinosa (López-Uribe et al. 2016)

154 was the only Cucurbita specialist pollinator species, and Acalymma vittatum the only obligate

155 herbivore species that were able to colonize the new temperate geographic areas where humans

156 introduced Cucurbita cultivars (Shapiro et al. 2018b). In the temperate Eastern United States,

157 Acalymma vittatum can transmit the virulent bacterial pathogen, Erwinia tracheiphila. This

158 pathogen does not occur anywhere else in the world outside of this limited geographic area, and

159 inferences from E. tracheiphila genomics studies suggest it was human-mediated changes to

160 cucurbit agro-ecosystems that recently drove its emergence in this region (Shapiro et al. 2015,

161 Shapiro et al. 2016, Andrade-Domínguez et al. 2018, Shapiro et al. 2018a, Shapiro et al. 2018b).

162

163 Insect collection:

164 Insects were field collected from flowers of healthy (ie, not infected with Erwinia tracheiphila)

165 wild and cultivated Cucurbita spp. host plants, and all insects per location came from the same

166 field or wild plant population (Table 1). Insects were killed in 95\% ethanol and stored at $-80 \mathrm{C}$.

167 Beetles were identified to species by LRS, and bees were identified to species by MMLU.

169 DNA extraction and sequencing:

170 To degrade surface DNA, ethanol-preserved insects were immersed in $10 \%$ CoveragePlus for

$17130 \mathrm{sec}$ and then rinsed in molecular grade water for 10s. After surface DNA degradation, the 
172 whole insect was pre-ground with a bleach treated plastic pestle, and homogenized with a bead

173 beater at the highest settings for $1 \mathrm{~min}$. DNA was extracted from ground whole insects using

174 Zymo Microbiomics (Tustin, CA) extraction kit following manufacturer's instructions. The

175 extracted DNA in each sample was quantified with Qubit Broad Spectrum Kit (Thermofisher),

176 and the concentration in all samples was standardized to $10 \mathrm{ng} / \mu \mathrm{l}$ to be used as PCR template.

177 Each DNA sample was amplified in triplicate using the bacterial 16S primers F515 (5'-

178 GTGCCAGCMGCCGCGGTAA-3') and R806 (5'-GGACTACHVGGGTWTCTAAT- 3'),

179 specific for the V4 region of $16 \mathrm{~S}$ rRNA. In addition to the region specific for $16 \mathrm{~S}$ rRNA

180 hybridization, these oligonucleotides contain adapter, primer pad and linker sequences for

181 Illumina (Supplemental Table 5). One unique reverse primer was used for each sample, which

182 also contained a distinctive 12 nucleotide GoLay barcode (Supplemental Table 5) (Caporaso et

183 al. 2011). Each $25 \mu 1$ PCR reaction contained $0.25 \mu$ of Q5 High Fidelity polymerase (New

184 England Biolabs), $0.5 \mu \mathrm{l}$ of $10 \mathrm{mM}$ dNTPs, $500 \mathrm{nM}$ of each primer and $5 \mu \mathrm{l}$ of $5 \mathrm{X}$ Q5 reaction

185 buffer. The PCR cycle program was: denaturation at $98^{\circ} \mathrm{C}$ for $30 \mathrm{~s}$, then 35 cycles of $98^{\circ} \mathrm{C}$ for 10

$186 \mathrm{~s}, 60^{\circ} \mathrm{C}$ for $30 \mathrm{~s}$, and $72^{\circ} \mathrm{C}$ for $20 \mathrm{~s}$; finally, $72 \square \mathrm{C}$ for $2 \mathrm{~min}$. The PCR products were checked

187 via agarose gel electrophoresis for the correct size PCR product as a visual quality control. The

188 three triplicate PCR products per sample were then pooled, gel purified using a Gel Purification

189 Kit (Zymo Research, Tustin CA), and quantified using Qubit Broad Range kit (Thermofisher).

190 Equal quantities of the pooled triplicates from each sample were then combined. This final pool

191 containing all libraries was prepared for Illumina MiSeq sequencing by diluting to $4 \mathrm{nM}$ and then

192 denatured by mixing 1:1 with $0.2 \mathrm{~N} \mathrm{NaOH}$, for a final concentration of $2 \mathrm{nM}$ of DNA and $0.1 \mathrm{~N}$

$193 \mathrm{NaOH}$. The pooled libraries were then mixed with 1 volume of $2 \mathrm{nM}$ denatured PhiX Sequencing

194 Control (Illumina). Three primers were used for sequencing: read 1 of 251 cycles (5'- 
TATGGTAATTGTGTGCCAGCMGCCGCGGTAA-3'), read 2 for 251 cycles (5'-

196

197

198

199 greengenes is accurate. When BLASTN provided a more accurate taxonomic assignment, that

212 assignment was added in a separate column to the OTUs in the taxonomy files (Supplemental

\section{Tables 1, 2, 3, 4).}

All statistical analyses were carried out in the R statistical computing environment (Team 2015) following the general pipelines established in phyloseq (McMurdie and Holmes 2013).

217 Supplemental Table 4) had only 2 total reads and was excluded from all analyses due to low 
218 sequencing coverage. OTUs that were assigned as chloroplast or mitochondria were filtered out

219 of the OTU table, and Wolbachia OTUs were filtered to a new biom table to be analyzed

220 separately. Phyloseq was used to rarefy the number of all reads per sample to 1,000, and these

221 rarefied sample sums were used to quantify Shannon and Simpson $\alpha$-diversity indices. Eight

222 additional beetles (\#SampleID 259, 280, 271, 187, 239, 175, 247, 151; Supplemental Table 4)

223 had fewer than 1000 reads and were removed from only the $\alpha$-diversity quantification. These

224 eight individuals were retained in all other analyses. For analyses other than $\alpha$-diversity, read

225 counts were normalized to the total number of reads obtained for each individual sample

226 (McMurdie and Holmes 2014). To calculate $\beta$-diversity, only the top 30 most abundant OTUs for

227 the three sub-groups of samples were used (Acalymma collected from different states; Acalymma

228 vittatum collected within a season; and Eucera (P.) pruinosa). Distance matrices were calculated

229 using unweighted Unifrac, and a PcoA of these distances were constructed using Phyloseq and

230 custom scripts (McMurdie and Holmes 2013). A PERMANOVA adonis test on the unweighted

231 Unifrac distance matrix was implemented in vegan (Dixon 2003). All plots were created with

232 phyloseq (McMurdie and Holmes 2013) and ggplot2 (Wickham 2016).

\section{Results}

235 Sequencing Summary

236 In the United States, Eucera (P.) pruinosa samples were collected from cultivated Cucurbita

237 plants in Pennsylvania and California. Acalymma vittatum and A. trivittatum were collected from

238 cultivated plants in New Mexico, Arizona, Alabama, Iowa, Kentucky, Massachusetts and

239 Vermont in the United States. Acalymma trivittatum were also collected from wild Cucurbita

240 plants in Queretero, Mexico. At each location, all insects were sampled from the same 
241 agricultural field, or same wild plant population. In total, bacterial communities of 59 Acalymma

242 beetles and 11 Eucera pruinosa bee individuals were sequenced (Figure 1a and 1b, Table 1).

243 Sequencing the V3-V4 region of the 16S rRNA gene resulted in an average of 13,696 reads per

244 sample (when grouped at 97\% similarity, and after filtering out reads belonging to OTUs

245 assigned to chloroplast, mitochondria and Wolbachia). There were 1,326 unique de novo OTUs

246 overall, which were classified into 17 unique phyla and 149 unique families.

248 Acalymma vittatum and A. trivittatum microbiome composition and geographic variation

249 There were a total of 1,179 unique de novo OTUs present in the 59 sequenced Acalymma leaf

250 beetle samples, and an average of 148 OTUs in each individual beetle. There are 16 OTUs that

251 each comprise at least $1 \%$ of the total bacterial abundance, and collectively these 16 OTUs

252 account for $83 \%$ of the total bacterial abundance across all the Acalymma individuals analyzed

253 (Supplemental Table 1). These 16 OTUs belong to Gammaproteobacteria (50\%; 8 of 16),

254 Betaproteobacteria (12.5\%; 2 of 16), Lactobacillales (12.5\%; 2 of 16), Bacteroidetes (12.5\%; 2

255 of 16) and Actinobacteria (6.25\%; 1 of 16$)$.

256 The taxonomic distribution of the 1,163 remaining rare OTUs (that are each present as

257 less than $1 \%$ of the overall bacterial abundance) is similar to the taxonomic distribution of the 16

258 most common OTUs. Most of the rare OTUs are from Proteobacteria (44\%; 514 out of 1163),

259 followed by OTUs from Firmicutes (26\%; 304 out of 1163), Actinobacteria (18.5\%; 215 out of

260 1163), Chloroflexi (3.4\%; 39 out of 1163) and Bacteroidetes (2.9\%; 34 out of 1163). Other rare,

261 low abundance OTUs are assigned to Acidobacteria, Verrucomicrobia, Plantomycetes,

262 Mollicutes and several Archeal phyla (Funaro et al. 2011, Abdul Rahman et al. 2015, Alves et al.

263 2016). There was moderate statistical support for differences in the $\alpha$-diversity (number and 
264 evenness) of OTUs in beetles collected in the different geographic locations (Kruskal-Wallis $\chi^{2}=$

$26511.9, \mathrm{df}=6, P=0.06)$, but there is no clear geographic factor underlying these differences

266 (Figure 2). The bacterial community composition of beetles collected in the different states is

267 qualitatively different overall (adonis PERMANOVA on unweighted UniFrac distances of the 30

268 most abundant OTUs; $\mathrm{df}=6, P \leq 0.01$ ). Beetles collected from Iowa (USA) have the most

269 homogeneous communities, while beetles collected from Arizona (USA) and Querétaro (MX) -

270 both locations in the ancestral native range of $A$. vittatum - have the most variable composition.

272 Within-season variation of Acalymma vittatum bacterial communities

273 To quantify how seasonality affects the composition of beetle gut bacterial communities, adult

274 Acalymma vittatum were collected from cultivated Cucurbita plants in Cambridge,

275 Massachusetts (USA) soon after emerging from diapuase in the spring (June 7, 2016), from the

276 second generation in the middle of the growing season (July 12, 2016), and from the diapausing

277 generation towards the end of the growing season (August 14, 2016). There is high variability in

$278 \alpha$-diversity in individual A. vittatum collected throughout a single season, and no time point had

279 significantly higher or lower $\alpha$-diversity than the others (Kruskal-Wallis $\chi^{2}=0.61, \mathrm{df}=2, P=$

280 0.74) (Figure 3). However, the composition of beetle bacterial communities does significantly

281 change over the course of the growing season (adonis PERMANOVA on unweighted UniFrac

282 distances of the 30 most abundant OTUs df $=2, P \leq 0.01)$. Beetles collected soon after emerging

283 from underground winter diapause (June 7, 2016) have higher abundances of Actinomycetales

284 and Cytophagales - which are thought to predominantly be soil-dwelling species - than the other

285 two time points. Beetles collected in the middle of the season (July 12, 2016), when many

286 Cucurbita cultivars are flowering (and beetles are likely consuming protein-rich pollen and 
sugar-rich nectar (Samuelson 1994, Sasu et al. 2010a, Shapiro et al. 2012)) have the highest

288 abundance of Lactobacillales. Bacterial communities of beetles collected on August 14 are

289 dominated by OTUs assigned to Enterobacteriales and Pseudomonadales, which are likely

290 derived from foliar tissue.

292 Prevalence of Erwinia tracheiphila in Acalymma vittatum and A. trivittatum beetles

293 Erwinia tracheiphila cannot be differentiated from closely related Erwinia and Pantoea strains

294 with certainty from the sequences of V3-V4 rRNA gene fragments. To be conservative about

295 estimating E. tracheiphila prevalence and abundance, all OTUs that were assigned to

296 Enterobacteriaceae, and their taxonomic assignments were manually curated. Eight OTUs had at

297 least a 98\% sequence similarity to E. tracheiphila as the first or second BLASTN (Altschul et al.

298 1990) hit (using the NCBI rRNA reference database), and the prevalence and abundance of these

299 OTUs were combined and all considered as putative E. tracheiphila (Supplemental File 3). Even

300 using this permissive criteria that almost certainly over-estimates E. tracheiphila presence, only

30133 out of the 59 Acalymma beetles harbor any of these putative E. tracheiphila OTUs (Table 2).

302 When E. tracheiphila OTUs are detected in an individual beetle, they never sum to more than

$3031 \%$ of the total bacterial abundance within that insect (Table 2). Surprisingly, E. tracheiphila

304 OTUs are detected not only in Acalymma beetles collected in temperate Easterns regions where

305 this pathogen causes annual epidemics, but was also detected in a number of beetles collected

306 from Tucson, AZ, USA and Querétero, MX - areas far from where E. tracheiphila is known to

307 occur. This suggests there may be Erwinia strains or species closely related to Erwinia

308 tracheiphila that may be common, non-pathogenic commensals of wild Cucurbita plants. 
311 Overall, there is a total of 312 distinct de novo OTUs present in at least one of the 11 sequenced

312 Eucera (P.) pruinosa samples (Table 1, Supplemental Table 2). There is an average of 93 OTUs

313 in each individual bee collected in California, while there is an average of only 30 OTUs in each

314 bee collected in Pennsylvania. There are 14 OTUs that comprise at least $1 \%$ of the total bacterial

315 abundance, and these 14 OTUs collectively sum to $89.6 \%$ of the total bacterial abundance in the

316 Eucera bee samples. Of the 14 common OTUs, 6 are assigned to Lactobacillales (Bacilli), 5 are

317 assigned to Enterobacteriales and Pseudomonadales (Gammaproteobacteria), 1 is assigned to

318 Actinobacteria and 1 to Entoplasmatales (Mollicutes). The most abundant OTU in E. (P.)

319 pruinosa (de novo 415107) is assigned to Acinetobacter (Gammaproteobacteriaceae), a genus

320 with many species commonly associated with floral nectar (Álvarez-Pérez et al. 2013,

321 McFrederick and Rehan 2016). The Lactobacillales OTUs are likely involved in breakdown of

322 pollen, and/or fermentation of nectar carbohydrates (McFrederick et al. 2012, McFrederick et al.

323 2018, Vuong and McFrederick 2019). Pollen is very high in fructose, and one of the 14 common

324 OTUs is assigned to Fructobacillus (de novo 382787), which may also function to breakdown

325 sugar in pollen and nectar (Endo and Salminen 2013). The same Fructobacillus OTU is

326 occasionally present in Acalymma, but at extremely low abundance Supplemental Table 1). One

327 of the 14 common E. (P.) pruinosa OTUs is assigned to Spiroplasma sp. nr. apis

328 (Entoplasmatales) (de novo 410890), and is common in bees collected in both CA and PA. Some

329 Entoplasmatales species are ancient commensals of insects (Funaro et al. 2011), while other

330 species are emerging as pathogens of wild and managed bees (Ravoet et al. 2014). Of the 299

331 rare OTUs that comprise the remaining $11 \%$ of bacterial abundance, most OTUs are assigned to

332 Gammaproteobacteria (43\%; 129 out of 299), followed by Lactobacillales (37\%; 111 out of 
333 299), Actinobacteria (6\%; 19 out of 299) and Entomoplasmatales (3.7\%; 11 out of 299)

334 (Supplemental Table 2). E. (P.) pruinosa collected in California have marginally higher average

$335 \alpha$-diversity (Kruskal-Walls $\chi^{2}=1.75$, df $=1, P=0.18$ ) (Figure 4), and the bacterial communities

336 from bees sampled in CA vs. PA are marginally qualitatively different (adonis PERMANOVA

337 on unweighted UniFrac distances of the 30 most abundant OTUs df $=2, P=0.09$ ).

340 Despite the high total number of de novo bacterial OTUs, six of the top 7 most abundant OTUs

341 in Acalymma beetles are also among the 14 most abundant OTUs in Eucera bees (Supplemental

342 Table 1, Supplemental Table 2, (Figure 5) (Herrera et al. 2009, Fridman et al. 2012). As

343 expected, the taxonomic assignments of the OTUs found in E. pruinosa reflect microbes that are

344 likely well-adapted to aid in digestion of the floral food sources. Surprisingly, many of these

345 same common OTUs are found in Acalymma, suggesting that floral pollen and nectar may be an

346 unappreciated nutritional source for these beetles, which are generally thought of as leaf

347 herbivores due to the extensive foliar economic damage they inflict (Baker and Hurd Jr 1968,

348 Samuelson 1994, Shapiro et al. 2012). A Klebsiella spp. OTU (de novo 423191) is the most

349 abundant overall in Acalymma beetles, and the second most abundant in bees. Two

350 Lactobacillales OTUs (de novo 432933 and de novo 222965), an Enterobacteriaeae (de novo

351 264045), an Acinetobacter (de novo 213309), and an Actinomycetales (de novo 211172) are also

352 among the most common OTUs in both bees and beetles (Supplemental Table 4). This suggests

353 these insects are exposed to these same OTUs through their shared floral food sources, and that

354 these common OTUs may perform similar digestive functions related to breakdown of sugars

355 (and perhaps proteins and fats) present in Cucurbita pollen and nectar. 
357 Detection of Wolbachia in Acalymma

358 Ten percent of Acalymma vittatum (6 out of 59 individuals) were infected with Wolbachia. This

359 is consistent with a previous study that found a 5\% Wolbachia infection rate of field-collected $A$.

360 vittatum (Clark et al. 2001). All Wolbachia-positive beetles were collected from temperate

361 Eastern North America (Massachusetts, Kentucky and Vermont) (Supplemental Figure 1). No

362 Acalymma collected outside of the E. tracheiphila endemic area carried Wolbachia, and none of

363 the E. (P.) pruinosa were positive for Wolbachia. The presence of Wolbachia in few beetles

364 collected from within their newly expanded geographic range in temperate Eastern North

365 America may be due to a recent shift of this reproductive parasite into A. vittatum as a host

366 species. A better understanding of the effects of harboring Wolbachia on A. vittatum

367 reproduction and population dynamics may be useful for developing sustainable vector control

368 strategies (Clark et al. 2001, Kajtoch and Kotásková 2018).

370 Discussion

371 Here, we find that field-collected Acalymma vittatum and trivittatum beetles, and to a lesser

372 extent Eucera (P.) pruinosa bees are exposed to diverse bacteria during normal foraging. Squash

373 bees and beetles have co-evolved to specialize on Cucurbita, and are both attracted over long

374 distances to the large, yellow, highly scented flowers that secrete substantial quantities of sugary

375 nectar, and produce large amounts of protein rich pollen (Metcalf and Lampman 1991, Mena

376 Granero et al. 2005, Shapiro et al. 2012). Cucurbita flowers, when present, are a foraging site

377 that likely also serves as a shared source of microbial exposure for both Acalymma and Eucera

378 (Peponapis) (Baker and Hurd Jr 1968, Samuelson 1994, Salzman et al. 2018). Consumption of 
floral resources with the same nutrient and carbohydrate composition by both beetles and bees

380 also likely drives the need for microbial associates that have the same metabolic functions for

381 plant matter digestion.

The trend towards higher $\alpha$-diversity in bees from California may be an artifact from the

383 low sample sizes of bees sequenced in this study. Alternatively, this trend may reflect that in

384 their native range, pollinators are exposed to a higher diversity of microbes while foraging on

385 multiple co-occuring species of Cucurbita, and on both wild and cultivated genotypes.

386 Populations of cultivated crops that are grown in homogeneous, human-managed landscapes

387 have reduced genetic diversity compared to populations of wild relatives, and may also host

388 microbial communities with lower diversity - measured as either 16S OTU richness, or total

389 physiological potential of the microbial community. The susceptibility of crop plants grown in

390 homogeneous, human managed agro-ecosystems to invasion by novel microbial pathogens is a

391 well-documented and continuing risk (McDonald and Stukenbrock 2016, Shapiro et al. 2016,

392 Shapiro et al. 2018b). How these homogeneous landscapes potentially also affect pollinator

393 health through alterations in microbial ecology, perhaps by creating landscapes with lower

394 microbial functional diversity, or increasing opportunities where wild and managed pollinators

395 can exchange pathogens, remains unknown (Colla et al. 2006, Burke et al. 2011, Fürst et al.

396 2014, López-Uribe et al. 2016, McDonald and Stukenbrock 2016, Shapiro et al. 2016, Pérez-

397 Jaramillo et al. 2017, Shapiro et al. 2018b, SA et al. 2019, Yu et al. 2019).

398 The high number of rare, low abundance OTUs in Acalymma herbivores is consistent with

399 accumulating evidence that the local environment - ie, the variable and diverse microbial

400 communities that colonize plants or the surrounding soil - are the most significant source of

401 microbial exposure for most non-social and non-sap feeding insects (Moran 2003, Kwong and 
Moran 2016, Hammer et al. 2017, McFrederick et al. 2017, Hammer et al. 2019, Hannula et al. 2019). The lower average number of OTUs per insect in bees compared to beetles may reflect that bees exclusively feed on Cucurbita floral resources, while Acalymma beetles are often found

405 feeding on other introduced cucurbit crop plants (most notably muskmelon and cucumbers, both

406 Cucumis spp.), consume both foliage and floral structures, and can occasionally be found feeding

407 on pollen from distantly related plant species (Gould 1944). Acalymma are highly mobile, and 408 move frequently between foliage and flowers of different host plants and the surrounding soil

409 during normal foraging, feeding and oviposition. The large geographic area from which beetles

410 were sampled may also contribute to the high number of rare OTUs. Overall, the composition

411 and diversity patterns reflect that Acalymma beetles are transiently exposed to diverse bacteria

412 that do not persistently colonize them as hosts (Hammer et al. 2017, Hammer et al. 2019).

413 A diminishingly small proportion of the gut bacterial community in field-collected $A$.

414 vittatum are OTUs that could be Erwinia tracheiphila. The low abundance of E. tracheiphila

415 OTUs in beetle vectors is consistent with laboratory experiments to quantify E. tracheiphila in

416 beeltes, and field studies to quantify transmission rates. In controlled laboratory experiments,

417 populations of E. tracheiphila in infective vectors or frass were too low to be detected by

418 standard PCR (Mitchell and Hanks 2009) but can be reliably detected by more sensitive

419 fluorescent probe-based qPCR assays (Shapiro et al. 2014). In field trials conducted at Rock

420 Springs Experimental Station in Central Pennsylvania (USA), almost all Cucurbita plants were

421 exposed to E. tracheiphila every morning by beetles that gather to feed and mate in flowers

422 (Sasu et al. 2010a). Despite this daily exposure to E. tracheiphila deposited by vectors, less than

423 half of the experimental plants developed an active E. tracheiphila infection (Sasu et al. 2009,

424 Sasu et al. 2010b). Genotypes of Cucurbita that produce more flowers, and more volatiles per 
425 flower - and therefore attract more foraging beetle vectors - are also associated with a

426 significantly higher rate of E. tracheiphila infection in Cucurbita pepo (Sasu et al. 2009, Shapiro

427 et al. 2012). This suggests that individual vectors deposit few E. tracheiphila cells during each

428 feeding exposure, and that cumulative exposure to many infective vectors is more important than 429 exposure to a single vector (Yao 1996).

430 The composition, function and variation of microbial communities that associate with

431 most wild, unmanaged insect species is almost completely unknown. This study is the first step

432 towards understanding factors underlying variation in the composition of bacterial communities

433 that associate with the ecologically and economically important insect species that have co-

434 evolved with Cucurbita. These results provide an important baseline for guiding future

435 experimental studies to understand factors driving variation in bacterial community composition

436 and functions. A more comprehensive understanding of which microbial strains and communities

437 colonize Eucera and Acalymma across the diverse geographic they inhabit, and empirically

438 testing the functions of individual isolates and more complex communities for the host insects

439 will be important for developing effective vector controls and protecting pollinator health.

\section{Acknowledgements}

442 LRS was supported by NSF postdoctoral fellowship DBI-1202736 and a grant from the North

443 Carolina State Plant Soil Microbe Collaborative Consortium; JR was supported by Fundación

444 Mexico en Harvard, and CONACYT grant 237414. We thank Roberto Kolter for experimental

445 support and advice, Nick Sloff for Figure 1A beetle image, and Clubes de Ciencias Mexico,

446 Ricardo Bessin, Salvador Montes, the University of Vermont Horticultural Farm and the

447 gardeners at the Christian Herter Community Garden for assistance collecting beetles; the 
448 Harvard Odyssey high performance computational cluster for computing resources and Harvard

449 Odyssey staff for compuational support. Mention of trade names or commercial products in this

450 publication is solely for the purpose of providing specific information and does not imply

451 recommendation or endorsement by the U.S. Department of Agriculture. Any opinions, findings,

452 conclusion, or recommendations expressed in this publication are those of the author(s) and do

453 not necessarily reflect the views of the U.S. Department of Agriculture.
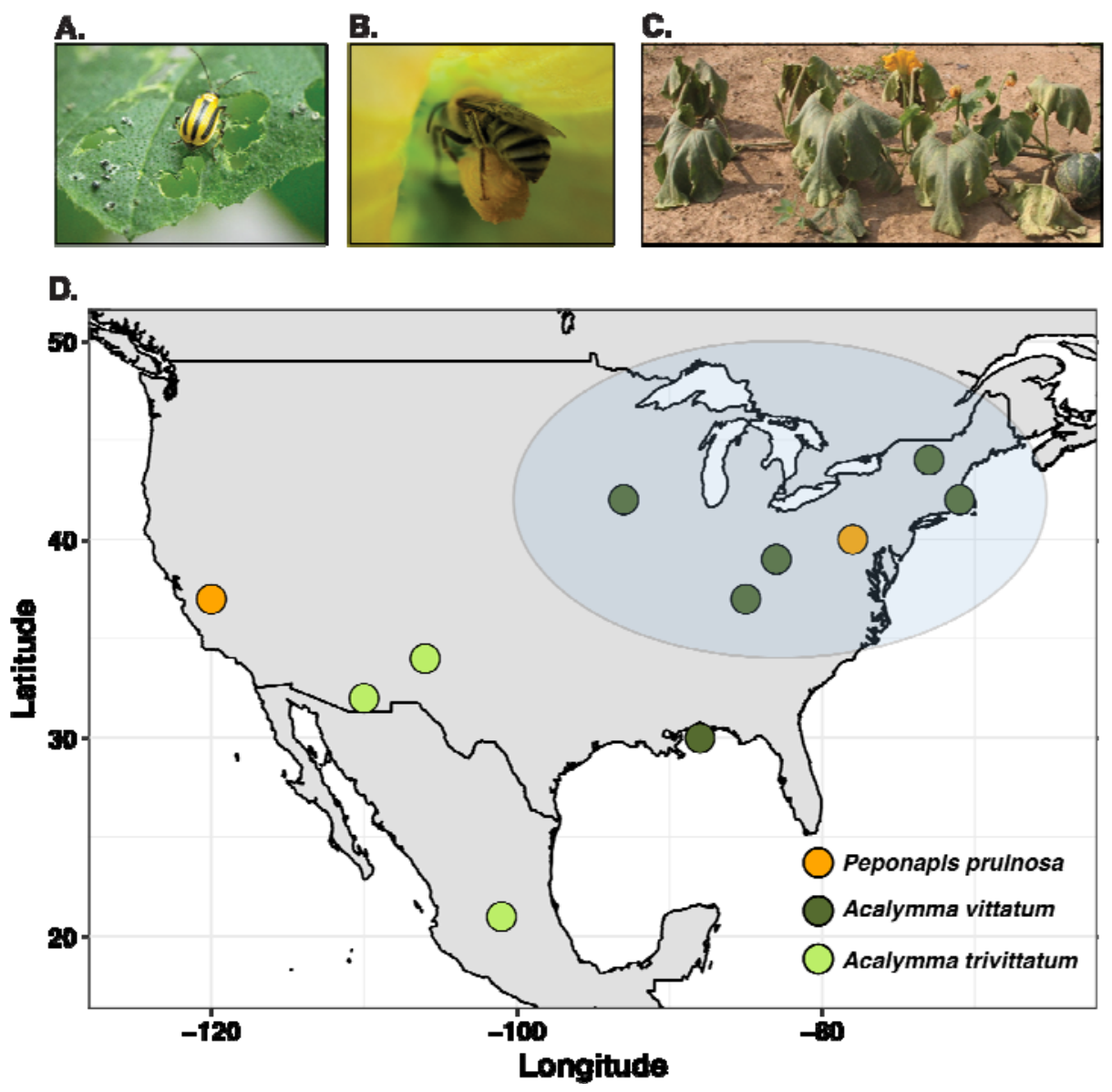

\section{Figure 1: The study system.}

A) The Eastern striped cucumber beetle, Acalymma vittatum resting on a Cucurbita pepo leaf 
temperate Eastern North America, and is the predominant vector driving Erwinia tracheiphila transmission dynamics

463 B) The Eastern squash bee, Eucera (Peponapis) pruinosa, gathering pollen and nectar from a male Cucurbita pepo flower approximates the region where Erwinia tracheiphila is an annual epidemic

A.

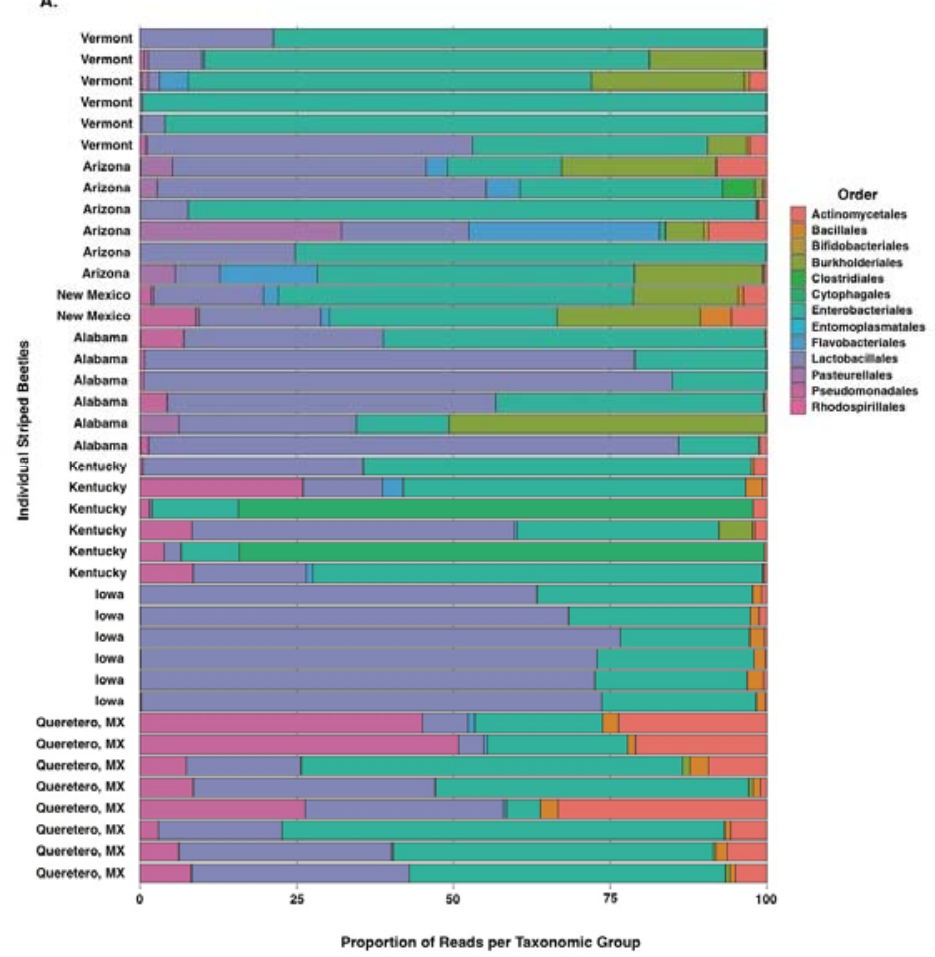

B.

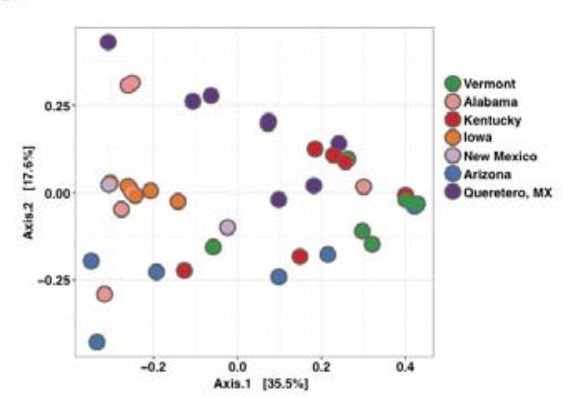

c.

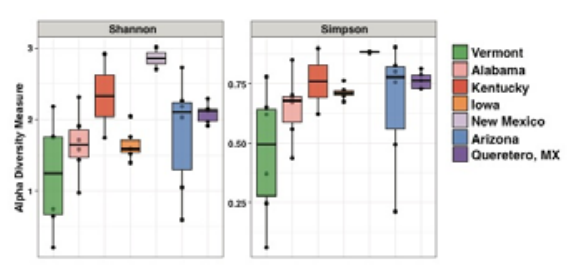

469

\section{Figure 2: Summary of bacterial community composition of Acalymma vittatum and}

\section{trivittatum}

A) Bacterial community composition of individual Acalymma vittatum and trivittatum beetles. Each horizontal bar is the bacterial community composition in an individual beetle. The collection location of each sample is labeled on the Y-axis. Community composition is displayed by combining OTUs within each order, and the counts in each insect were normalized to the total number of reads in that individual and displayed as a percentage of the total community. B) Principle coordinates analysis ( $\mathrm{PCoA})$ of unweighted Unifrac distances, with each dot representing an individual insect. Insects are colored according to collection location. C) Shannon and Simpson $\alpha$-diversity indices for the bacterial communities of Acalymma vittatum and trivittatum collected from different geographic locations (corresponding to Table 1 and Figure 1D). The number of reads per insect was rarefied to an even depth of 1000. Black dots are individual insects, and boxplots show the median and the quartile variation. 
A.

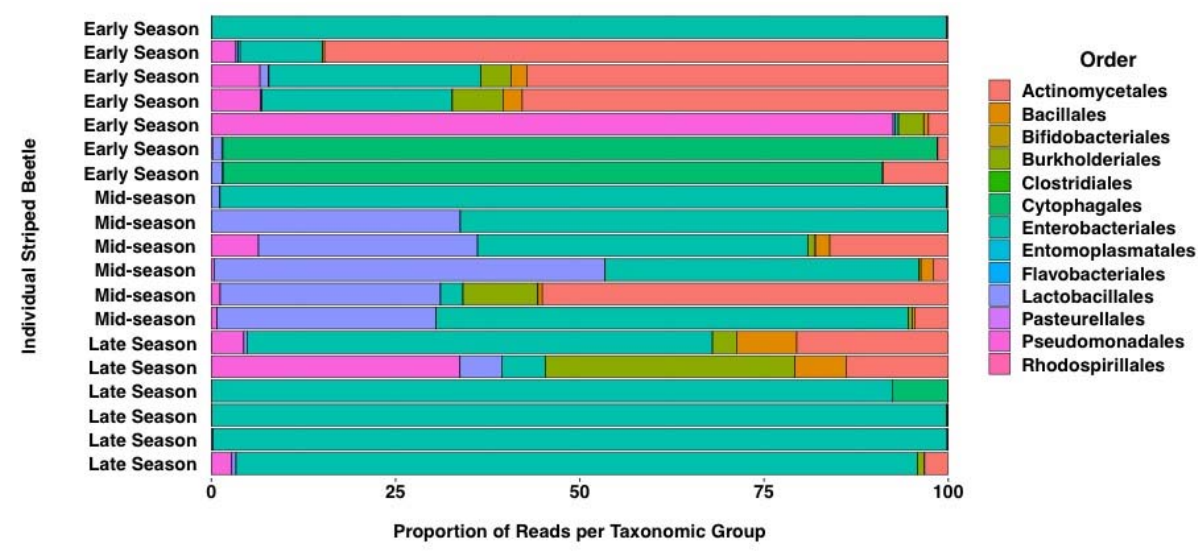

B.

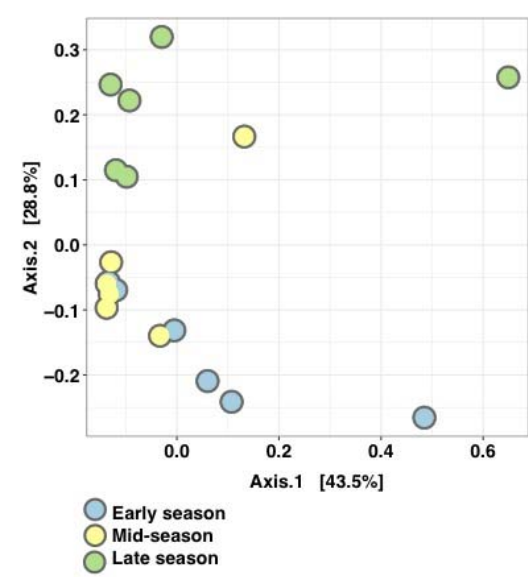

c.

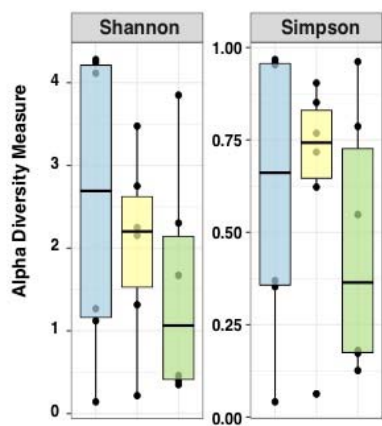

Figure 3: Seasonal variation of microbial communities from the same population of Acalymma vittatum in a Massachusetts.

487 A) Bacterial community composition of individual Acalymma vittatum beetles collected in Cambridge, Massachusetts. Beetles were collected early in the season as adults emerged from winter diapause and cucurbits had just being planted (June 7 2016); in the middle of the season when commercial summer squash are blooming (July 12 2016); and at the end of the season as the second generation was nearing diapause (August 2016). The collection group each insect belongs to is labeled on the Y-axis. Community composition is displayed by combining OTUs within each order, and the counts in each insect were normalized to the total number of reads in that individual and displayed as a percentage of the total community. B) Principle coordinates analysis $(\mathrm{PCoA})$ of unweighted Unifrac distances, with each dot representing an individual insect. Insects are colored according to date of collection. vittatum collected at three time points in a single growing season. The number of reads per insect was rarefied to an even depth of 1000. Black dots are individual insects, and boxplots show the median and the quartile variation. 
A.

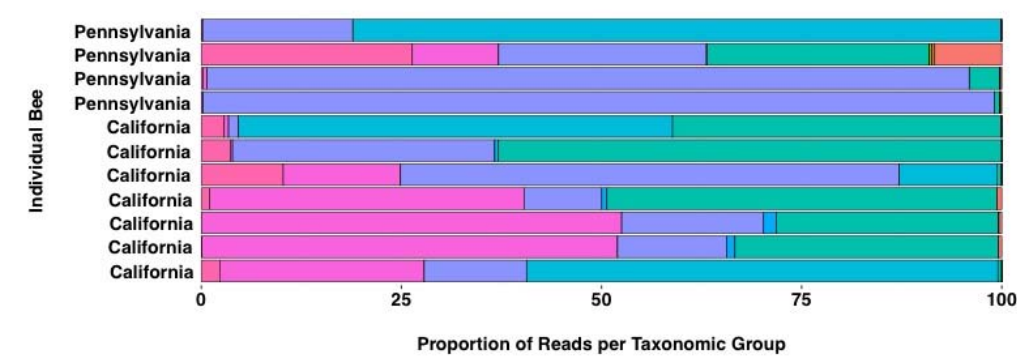

Order

Actinomycetale Bacillales Bifidobacteriales Burkholderiales Clostridiales Cytophagales

Entophagales

Enterobacteriales

Flavobasmatal

Lavobacteriales

Lactobacillales

Pasteurellales

Rhodospirillales
B.

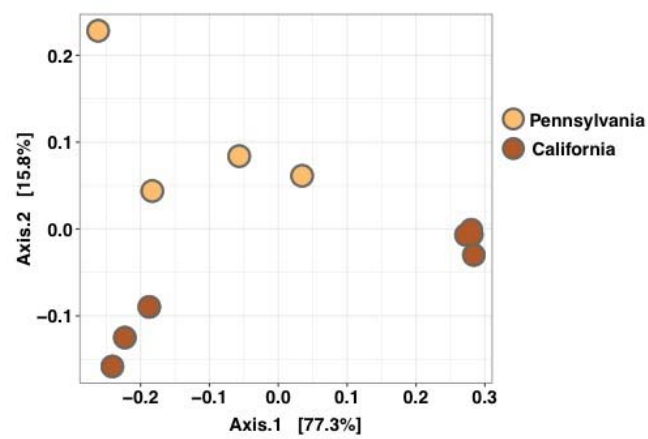

C.

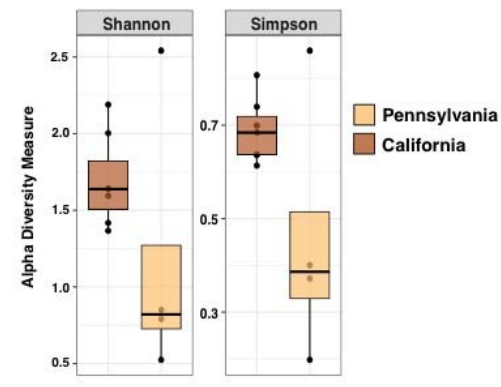

503 Figure 4: Geographic variation in Eucera (Peponapis) pruinosa bacterial communities.

504 A) Bacterial community composition of individual Eucera (P.) pruinosa bees collected in

505 California or Pennsylvania. The collection location of each sample is labeled on the Y-axis.

506 Community composition is displayed by combining OTUs within each order, and the counts in

507 each insect were normalized to the total number of reads in that individual and displayed as a

508 percentage of the total community.

509 B) Principle coordinates analysis (PCoA) of unweighted Unifrac distances, with each dot

510 representing an individual insect. Insects are colored according to collection location.

511 C) Shannon and Simpson $\alpha$-diversity indices for the gut bacterial communities of Eucera $(P$.)

512 pruinosa collected in California vs. Pennsylvania. The number of reads per insect was rarefied to

513 an even depth of 1000. Black dots are individual insects, and boxplots show the median and the

514 quartile variation. 


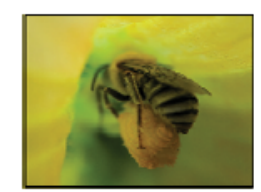

\section{Eucera prifinose}

California Pennsylvania

\section{Acalymma vittahm \& Acalymma trivittatum geographic variation}

\begin{tabular}{|l|l}
\hline$\square$ & Vermont \\
\hline$\square$ & Alabama \\
\hline & Kentucky \\
Iowa & \\
\hline$\square$ & New Mexico \\
\hline$\square$ & Artzona \\
\hline$\square$ Queretero, MX
\end{tabular}

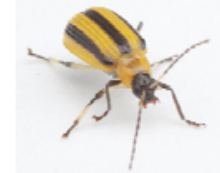

Acalymma vittatum within-season variation

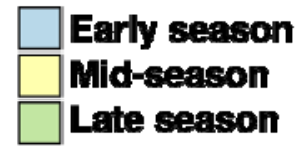

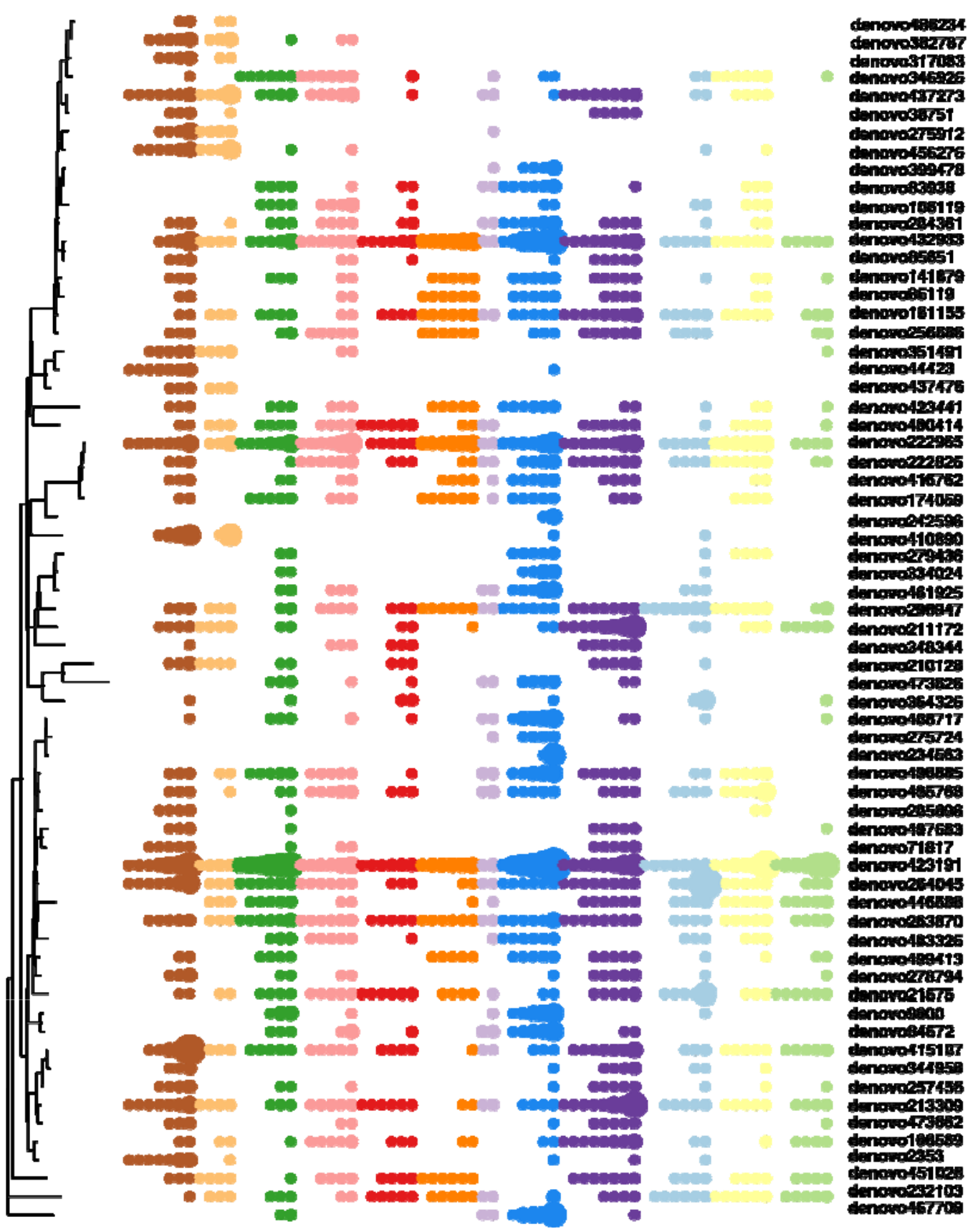


517 Figure 5: Prevalence and abundance of the most common bacterial OTUs in Acalymma 518 beetles and Eucera (Peponapis) bees.

519 The tree shows the phylogenetic distance relationships of the 50 most abundant OTUs in all 520 Acalymma beetles and the 40 most abundant OTUs in the Eucera (P.) pruinosa bees. Each tip of

521 the tree is an individual OTU, and corresponds to taxonomic assignments provided in

522 Supplemental Table 4 Each colored dot represents the occurrence of that OTU in an individual

523 insect, and the size of the dot corresponds to the relative abundance of that OTU in that

524 individual.

525

526 Supplemental Figure 1: Wolbachia occurrence in Acalymma beetles.

Table 1: Collection location, date, and host plant for all insects sequenced in this study

\begin{tabular}{|c|c|c|c|c|c|c|}
\hline Insect Species & Collection Location & Host Plant & $\begin{array}{l}\text { Number of } \\
\text { Insects } \\
\text { Sequenced }\end{array}$ & Collection Date & Lattitude & Longitude \\
\hline Acalymma vittatum & $\begin{array}{c}\text { Christian Herter } \\
\text { Community Garden, } \\
\text { Watertown, } \\
\text { Massachusetts }\end{array}$ & $\begin{array}{c}\text { Cultivars of } \\
\text { Cucurbita spp. in a } \\
\text { diverse community } \\
\text { garden }\end{array}$ & 6 & June 7, 2016 & 42.366338 & -71.134525 \\
\hline Acalymma vittatum & $\begin{array}{c}\text { Christian Herter } \\
\text { Community Garden, } \\
\text { Watertown, } \\
\text { Massachusetts }\end{array}$ & $\begin{array}{c}\text { Cultivars of } \\
\text { Cucurbita spp. in a } \\
\text { diverse community } \\
\text { garden }\end{array}$ & 7 & July 12, 2016 & 42.366338 & -71.134525 \\
\hline Acalymma vittatum & $\begin{array}{c}\text { Christian Herter } \\
\text { Community Garden, } \\
\text { Watertown, } \\
\text { Massachusetts }\end{array}$ & $\begin{array}{c}\text { Cultivars of } \\
\text { Cucurbita spp. in a } \\
\text { diverse community } \\
\text { garden }\end{array}$ & 6 & August 14, 2016 & 42.366338 & -71.134525 \\
\hline Acalymma vittatum & $\begin{array}{c}\text { University of Vermont } \\
\text { Horticultural Farm, } \\
\text { Burlington, Vermont }\end{array}$ & $\begin{array}{l}\text { Cucurbita pepo } \\
\text { (Zucchini) }\end{array}$ & 6 & August 8, 2015 & 44.430052 & -73.204011 \\
\hline Acalymma vittatum & $\begin{array}{l}\text { lowa State University } \\
\text { Horticultural Research } \\
\text { Station, Ames lowa }\end{array}$ & $\begin{array}{l}\text { Cultivated } \\
\text { Cucurbita spp. and } \\
\text { Cucumis spp. } \\
\text { cultivars }\end{array}$ & 6 & August 18, 2016 & 42.107812 & -93.589034 \\
\hline Acalymma vittatum & $\begin{array}{c}\text { Gulf Coast Research } \\
\text { and Extension Center, } \\
\text { Mobile, Alabama }\end{array}$ & $\begin{array}{c}\text { Cultivars of } \\
\text { Cucurbita spp. }\end{array}$ & 6 & June 3, 2015 & 30.547286 & -87.88255 \\
\hline Acalymma vittatum & $\begin{array}{c}\text { University of Kentucky } \\
\text { Horticultural Research } \\
\text { Farm, Lexington, } \\
\text { Kentucky }\end{array}$ & $\begin{array}{l}\text { Acorn squash plot } \\
\text { (Cucurbita pepo) }\end{array}$ & 6 & August 9, 2016 & 37.976154 & -84.533393 \\
\hline Acalymma trivittatum & New Mexico & $\begin{array}{l}\text { Wild roadside } \\
\text { Cucurbita } \\
\text { foetidissima }\end{array}$ & 2 & July 2, 2015 & 32.5225 & -108.730833 \\
\hline Acalymma trivittatum & $\begin{array}{c}\text { University of Arizona } \\
\text { Pima Outreach Center, } \\
\text { Tucson, Arizona }\end{array}$ & $\begin{array}{l}\text { Cultivars of } \\
\text { Cucurbita spp. and } \\
\text { Cucumis sativus in } \\
\text { demonstration } \\
\text { garden beds }\end{array}$ & 6 & July 7, 2015 & 32.282077 & -110.94240 \\
\hline Acalymma trivittatum & Quertaro, Mexico & $\begin{array}{l}\text { Wild Cucurbita } \\
\text { foetidissima on } \\
\text { roadside }\end{array}$ & 8 & July 28, 2016 & 20.6889 & -100.326 \\
\hline Peponapis pruinosa & California & $\begin{array}{l}\text { Flowers of } \\
\text { cultivated } \\
\text { Cucurbita }\end{array}$ & 7 & August 2, 2010 & 38.7678 & -122.0379 \\
\hline
\end{tabular}


bioRxiv preprint doi: https://doi org/10.1101/691378; this version posted July 3, 2019. The copyright holder for this preprint (which was not certified by peer review) is the author/funder, who has granted bioRxiv a license to display the preprint in perpetuity. It is made available under aCC-BY-NC-ND 4.0 International license.

\begin{tabular}{|l|l|l|l|l|l|} 
Peponapis pruinosa & Pennsylvania & $\begin{array}{l}\text { Flowers of } \\
\text { cultivated } \\
\text { Cucurbita }\end{array}$ & 4 & July 29, 2011 & 39.9461 \\
\hline
\end{tabular}

Table 2: Percentage of the total bacterial community in each individual insect that is Erwinia tracheiphila

\begin{tabular}{|c|c|c|c|c|}
\hline $\begin{array}{l}\text { Individual } \\
\text { Sample ID }\end{array}$ & Location & $\begin{array}{c}\text { Erwinia } \\
\text { tracheiphila } \\
\text { geographic zone }\end{array}$ & $\begin{array}{l}\text { Total Number } \\
\text { of Bacterial } \\
\text { Reads (top } 20 \\
\text { OTUs) }\end{array}$ & $\begin{array}{l}\text { *Total Number of } \\
\text { Reads in OTUs near } \\
\text { Erwinia tracheiphila }\end{array}$ \\
\hline
\end{tabular}

Percentage of total reads putatively Erwinia tracheiphila

\begin{tabular}{|c|c|c|c|c|c|}
\hline 6 & Massachusetts (early) & Yes & 1544 & 0 & 0 \\
\hline 203 & Massachusetts (early) & Yes & 387 & 0 & 0 \\
\hline 215 & Massachusetts (early) & Yes & 13763 & 1 & 0.0073 \\
\hline 239 & Massachusetts (early) & Yes & 623 & 0 & 0 \\
\hline 251 & Massachusetts (early) & Yes & 7488 & 0 & 0 \\
\hline 263 & Massachusetts (early) & Yes & 43316 & 18 & 0.0416 \\
\hline 275 & Massachusetts (early) & Yes & 247 & 0 & 0 \\
\hline 106 & Massachusetts (mid-season) & Yes & 10217 & 0 & 0 \\
\hline 118 & Massachusetts (mid-season) & Yes & 2972 & 4 & 0.1346 \\
\hline 155 & Massachusetts (mid-season) & Yes & 2990 & 2 & 0.0669 \\
\hline 167 & Massachusetts (mid-season) & Yes & 1448 & 1 & 0.0691 \\
\hline 179 & Massachusetts (mid-season) & Yes & 6280 & 1 & 0.0159 \\
\hline 191 & Massachusetts (mid-season) & Yes & 28553 & 4 & 0.0140 \\
\hline 90 & Massachusetts (late-season) & Yes & 732 & 0 & 0 \\
\hline 105 & Massachusetts (late-season) & Yes & 1160 & 5 & 0.4310 \\
\hline 117 & Massachusetts (late-season) & Yes & 19665 & 59 & 0.3000 \\
\hline 129 & Massachusetts (late-season) & Yes & 14516 & 59 & 0.4064 \\
\hline 141 & Massachusetts (late-season) & Yes & 1734 & 0 & 0 \\
\hline 165 & Massachusetts (late-season) & Yes & 2765 & 13 & 0.4702 \\
\hline 101 & Vermont & Yes & 5760 & 2 & 0.0347 \\
\hline 138 & Vermont & Yes & 22983 & 14 & 0.0609 \\
\hline 150 & Vermont & Yes & 7344 & 58 & 0.7898 \\
\hline 162 & Vermont & Yes & 6830 & 0 & 0 \\
\hline 174 & Vermont & Yes & 12054 & 27 & 0.2240 \\
\hline 186 & Vermont & Yes & 17541 & 6 & 0.0342 \\
\hline 260 & Alabama & No & 1041 & 0 & 0 \\
\hline 248 & Alabama & No & 2638 & 0 & 0 \\
\hline 236 & Alabama & No & 2518 & 0 & 0 \\
\hline 224 & Alabama & No & 4531 & 0 & 0 \\
\hline 212 & Alabama & No & 13223 & 2 & 0.0151 \\
\hline 200 & Alabama & No & 4651 & 7 & 0.1505 \\
\hline 268 & Kentucky & Yes & 1080 & 1 & 0.0926 \\
\hline 280 & Kentucky & Yes & 258 & 0 & 0 \\
\hline 283 & Kentucky & Yes & 1630 & 0 & 0 \\
\hline 271 & Kentucky & Yes & 455 & 0 & 0 \\
\hline 259 & Kentucky & Yes & 138 & 0 & 0 \\
\hline 247 & Kentucky & Yes & 641 & 0 & 0 \\
\hline 190 & lowa & Yes & 9058 & 2 & 0.0221 \\
\hline 272 & lowa & Yes & 10720 & 0 & 0 \\
\hline 166 & lowa & Yes & 3849 & 0 & 0 \\
\hline 154 & lowa & Yes & 2544 & 0 & 0 \\
\hline
\end{tabular}




\begin{tabular}{|c|c|c|c|c|c|}
\hline 142 & lowa & Yes & 6035 & 0 & 0 \\
\hline 130 & lowa & Yes & 4014 & 1 & 0.0249 \\
\hline 257 & New_Mexico & No & 2525 & 1 & 0.0396 \\
\hline 269 & New_Mexico & No & 1856 & 0 & 0 \\
\hline 216 & Arizona & No & 27221 & 1 & 0.0037 \\
\hline 204 & Arizona & No & 36866 & 19 & 0.0515 \\
\hline 40 & Arizona & No & 56257 & 0 & 0 \\
\hline 28 & Arizona & No & 48542 & 5 & 0.0103 \\
\hline 16 & Arizona & No & 51246 & 67 & 0.1307 \\
\hline 4 & Arizona & No & 57625 & 10 & 0.0174 \\
\hline 187 & Querétero MX & No & 557 & 0 & 0 \\
\hline 78 & Querétero $\mathrm{MX}$ & No & 14615 & 16 & 0.1095 \\
\hline 175 & Querétero $\mathrm{MX}$ & No & 644 & 2 & 0.3106 \\
\hline 163 & Querétero $\mathrm{MX}$ & No & 14801 & 15 & 0.1013 \\
\hline 151 & Querétero $\mathrm{MX}$ & No & 719 & 0 & 0 \\
\hline 139 & Querétero MX & No & 1469 & 1 & 0.0681 \\
\hline 127 & Querétero $\mathrm{MX}$ & No & 8398 & 58 & 0.6906 \\
\hline 66 & Querétero MX & No & 52178 & 483 & 0.9257 \\
\hline
\end{tabular}

*The number of reads in all individual putative Erwinia tracheiphila OTUs were summed

530 Supplemental Table 1: Taxonomic assignments of OTUs, the number of individuals in which that OTU occurs, and the percentage of each OTU in the cumulative community in Acalymma vittatum and trivittatum beetles. that OTU occurs, and the percentage of each OTU in the cumulative community in Eucera (P.) pruinosa squash bees.

Supplemental Table 3: Manual curation of OTUs assigned to Enterobacteriaceae to assess which are most likely to be Erwinia tracheiphila.

Supplemental Table 4: Manual curation of taxonomic assignments of the dominant OTUs in Acalymma and Eucera (Peponapis).

Supplemental Table 5: Primers, barcodes, and individual \#SampleIDs for the insects analyzed 545 in this study.

\section{References}


Alexandrova, M., B. Cimini, C. Bazzi, E. Carpana, S. Massi, and A. G. Sabatini. 2002. The role of honeybees in spreading Erwinia amylovora. Acta Horticulturae 590: 55-60.

Altschul, S. F., W. Gish, W. Miller, E. W. Myers, and D. J. Lipman. 1990. Basic local alignment search tool. Journal of Molecular Biology 215: 403-410.

Álvarez-Pérez, S., B. Lievens, H. Jacquemyn, and C. M. Herrera. 2013. Acinetobacter nectaris sp. nov. and Acinetobacter boissieri sp. nov., isolated from floral nectar of wild Mediterranean insect-pollinated plants. International Journal of Systematic and Evolutionary Microbiology 63: 1532-1539.

Alves, M., A. Pereira, P. Matos, J. Henriques, C. Vicente, T. Aikawa, K. Hasegawa, F. Nascimento, M. Mota, A. Correia, and I. Henriques. 2016. Bacterial community associated to the pine wilt disease insect vectors Monochamus galloprovincialis and Monochamus alternatus. Scientific Reports 6: 23908.

Andrade-Domínguez, A., R. Kolter, and L. R. Shapiro. 2018. Complete genome sequence of $\mathrm{EtG}$, the first phage sequenced from Erwinia tracheiphila. genomeA 6.

Baker, H. G., and P. D. Hurd Jr. 1968. Intrafloral ecology. Annual Review of Entomology 13: 385414.

Barber, H. 1946. Diabrotica and two new genera (Coleoptera, Chrysomelidae). Proceedings of the Entomological Society of Washington 49: 151-161.

Burke, C., P. Steinberg, D. Rusch, S. Kjelleberg, and T. Thomas. 2011. Bacterial community assembly based on functional genes rather than species. Proceedings of the National Academy of Sciences 108: 14288-14293.

Caporaso, J. G., K. Bittinger, F. D. Bushman, T. Z. DeSantis, G. L. Andersen, and R. Knight. 2009. PyNAST: a flexible tool for aligning sequences to a template alignment. Bioinformatics 26: 266-267.

Caporaso, J. G., C. L. Lauber, W. A. Walters, D. Berg-Lyons, C. A. Lozupone, P. J. Turnbaugh, N. Fierer, and R. Knight. 2011. Global patterns of $16 \mathrm{~S}$ rRNA diversity at a depth of millions of sequences per sample. Proceedings of the National Academy of Sciences 108: 45164522.

Caporaso, J. G., J. Kuczynski, J. Stombaugh, K. Bittinger, F. D. Bushman, E. K. Costello, N. Fierer, A. G. Pena, J. K. Goodrich, and J. I. Gordon. 2010. QIIME allows analysis of highthroughput community sequencing data. Nature Methods 7: 335-336.

Castellanos-Morales, G., L. M. Paredes-Torres, N. Gámez, H. S. Hernández-Rosales, G. Sánchez-de la Vega, J. Barrera-Redondo, E. Aguirre-Planter, A. Vázquez-Lobo, S. Montes-Hernández, and R. Lira-Saade. 2018. Historical biogeography and phylogeny of Cucurbita: Insights from ancestral area reconstruction and niche evolution. Molecular Phylogenetics and Evolution 128: 38-54.

Cellini, A., V. Giacom uzzi, I. Donati, B. Farneti, M. T. Rodriguez-Estrada, S. Savioli, S. Angeli, and F. Spinelli. 2019. Pathogen-induced changes in floral scent may increase honeybeemediated dispersal of Erwinia amylovora. The ISME Journal 13: 847.

Chambliss, O. L., and C. M. Jones. 1966. Cucurbitacins: specific insect attractants in Cucurbitaceae. Science 153: 1392-1393.

Chung, S. H., C. Rosa, K. Hoover, D. S. Luthe, and G. W. Felton. 2013. Colorado potato beetle manipulates plant defenses in local and systemic leaves. Plant Signaling \& Behavior 8: e27592. 
Clark, T. L., L. J. Meinke, S. R. Skoda, and J. E. Foster. 2001. Occurrence of Wolbachia in selected Diabroticite (Coleoptera : Chrysomelidae) beetles. Annals of the Entomological Society of America 94: 877-885.

Colla, S. R., M. C. Otterstatter, R. J. Gegear, and J. D. Thomson. 2006. Plight of the bumble bee: pathogen spillover from commercial to wild populations. Biological conservation 129: 461-467.

David, A., and D. Vallance. 1955. Bitter principles of Cucurbitaceae. Journal of Pharmacy and Pharmacology 7: 295-296.

Degnan, P. H., Y. Yu, N. Sisneros, R. A. Wing, and N. A. Moran. 2009. Hamiltonella defensa, genome evolution of protective bacterial endosymbiont from pathogenic ancestors. Proceedings of the National Academy of Sciences 106: 9063-9068.

DeSantis, T. Z., P. Hugenholtz, N. Larsen, M. Rojas, E. L. Brodie, K. Keller, T. Huber, D. Dalevi, P. Hu, and G. L. Andersen. 2006. Greengenes, a chimera-checked 16S rRNA gene database and workbench compatible with ARB. Applied and Environmental Microbiology 72: 5069-5072.

Dinan, L., P. Whiting, J.-P. Girault, R. Lafont, S. T. Dhadallia, E. D. Cress, B. Mugat, C. Antoniewski, and J.-A. Lepesant. 1997. Cucurbitacins are insect steroid hormone antagonists acting at the ecdysteroid receptor. Biochemical journal 327: 643-650.

Dixon, P. 2003. VEGAN, a package of R functions for community ecology. Journal of Vegetation Science 14: 927-930.

Eben, A., and A. Espinosa. 2013. Tempo and mode of evolutionary radiation in Diabroticina beetles (genera Acalymma, Cerotoma, and Diabrotica). Zookeys 332: 207-231.

Edgar, R. 2010a. Usearch. Lawrence Berkeley National Lab.(LBNL), Berkeley, CA (United States).

Edgar, R. C. 2010b. Search and clustering orders of magnitude faster than BLAST. Bioinformatics 26: $2460-2461$.

Endo, A., and S. Salminen. 2013. Honeybees and beehives are rich sources for fructophilic lactic acid bacteria. Systematic and Applied Microbiology 36: 444-448.

Ferguson, J. E., and R. L. Metcalf. 1985. Cucurbitacins. Journal of Chemical Ecology 11: 311-318.

Ferguson, J. E., R. L. Metcalf, and D. C. Fischer. 1985. Disposition and fate of cucurbitacin B in five species of diabroticites., pp. 1307-1321, J Chem Ecol.

Figueroa, L. L., M. Blinder, C. Grincavitch, A. Jelinek, E. K. Mann, L. A. Merva, L. E. Metz, A. Y. Zhao, R. E. Irwin, and S. H. McArt. 2019. Bee pathogen transmission dynamics: deposition, persistence and acquisition on flowers. Proceedings of the Royal Society B 286: 20190603.

Fleischer, S. J., D. de Mackiewicz, F. E. Gildow, and F. L. Lukezic. 1999. Serological estimates of the seasonal dynamics of Erwinia tracheiphila in Acalymma vittata (Coleoptera: Chrysomelidae). Environmental Entomology 28: 470-476.

Fraenkel, G. S. 1959. The raison d'etre of secondary plant substances Science 129: 1466-1470.

Fridman, S., I. Izhaki, Y. Gerchman, and M. Halpern. 2012. Bacterial communities in floral nectar. Environmental Microbiology Reports 4: 97-104.

Funaro, C. F., D. J. C. Kronauer, C. S. Moreau, B. Goldman-Huertas, N. E. Pierce, and J. A. Russell. 2011. Army ants harbor a host-specific clade of Entomoplasmatales bacteria. Applied and Environmental Microbiology 77: 346-350. 
Fürst, M., D. P. McMahon, J. Osborne, R. Paxton, and M. Brown. 2014. Disease associations between honeybees and bumblebees as a threat to wild pollinators. Nature 506: 364.

Gould, G. E. 1944. The biology and control of the striped cucumber beetle. Bulletin. Purdue University Experimental Station.

Hammer, T. J., J. G. Sanders, and N. Fierer. 2019. Not all animals need a microbiome. FEMS microbiology letters.

Hammer, T. J., D. H. Janzen, W. Hallwachs, S. P. Jaffe, and N. Fierer. 2017. Caterpillars lack a resident gut microbiome. Proceedings of the National Academy of Sciences 114: 96419646.

Hannula, S. E., F. Zhu, R. Heinen, and T. M. Bezemer. 2019. Foliar-feeding insects acquire microbiomes from the soil rather than the host plant. Nature Communications 10: 1254.

Herrera, C. M., C. de Vega, A. Canto, and M. I. Pozo. 2009. Yeasts in floral nectar: a quantitative survey. Annals of Botany 103: 1415-1423.

Hurd, P. D., and E. G. Linsley. 1964. The squash and gourd Bees - genera Peponapis (Robertson) and Xenoglossa (Smith) inhabiting America north of Mexico (Hymenoptera: Apoidea), University of Calif.

Hurd, P. D., and E. G. Linsley. 1967. South American squash and gourd bees of the genus Peponapis (Hymenoptera: Apoidea). Annals of the Entomological Society of America 60: 647-661.

Hurd, P. D., EG Linsley, and T. Whitaker. 1971. Squash and gourd bees (Peponapis, Xenoglossa) and the origin of the cultivated Cucurbita. Evolution 25: 218.

Hurd, P. D., E. G. Linsley, and A. E. Michelbacher. 1974. Ecology of the squash and gourd bee, Peponapis pruinosa, on cultivated cucurbits in California (Hymenoptera: Apoidea), Smithsonian Institution Press.

Kajtoch, Ł., and N. Kotásková. 2018. Current state of knowledge on Wolbachia infection among Coleoptera: a systematic review. PeerJ 6: e4471.

Kates, H. R., P. S. Soltis, and D. E. Soltis. 2017. Evolutionary and domestication history of Cucurbita (pumpkin and squash) species inferred from 44 nuclear loci. Molecular Phylogenetics and Evolution 111: 98-109.

Kistler, L., L. A. Newsom, T. M. Ryan, A. C. Clarke, B. D. Smith, and G. H. Perry. 2015. Gourds and squashes (Cucurbita spp.) adapted to megafaunal extinction and ecological anachronism through domestication. Proceedings of the National Academy of Sciences 112: 15107-15112.

Kwong, W. K., and N. A. Moran. 2016. Gut microbial communities of social bees. Nature Reviews Microbiology 14: 374.

López-Uribe, M. M., J. H. Cane, R. L. Minckley, and B. N. Danforth. 2016. Crop domestication facilitated rapid geographical expansion of a specialist pollinator, the squash bee Peponapis pruinosa. Proceedings of the Royal Society B: Biological Sciences 283: 20160443.

López-Villavicencio, M., O. Jonot, A. Coantic, M. E. Hood, J. Enjalbert, and T. Giraud. 2007. Multiple infections by the anther smut pathogen are frequent and involve related $680 \quad$ strains. PLoS Pathogens 3: e176. 
Mason, C. J., A. G. Jones, and G. W. Felton. 2018. Co-option of microbial associates by insects and their impact on plant-folivore interactions. Plant, Cell \& Environment 42: 10781086.

Mauck, K. E., Q. Chesnais, and L. R. Shapiro. 2018. Evolutionary determinants of host and vector manipulation by plant viruses. Advances in Virus Research 101: 189-250.

McArt, S. H., H. Koch, R. E. Irwin, and L. S. Adler. 2014. Arranging the bouquet of disease: floral traits and the transmission of plant and animal pathogens. Ecology Letters 17: 624-636.

McDonald, B. A., and E. H. Stukenbrock. 2016. Rapid emergence of pathogens in agroecosystems: global threats to agricultural sustainability and food security. Philosophical transactions - Royal Society. Biological sciences 371: 20160026.

McDonald, D., M. N. Price, J. Goodrich, E. P. Nawrocki, T. Z. DeSantis, A. Probst, G. L. Andersen, R. Knight, and P. Hugenholtz. 2012. An improved Greengenes taxonomy with explicit ranks for ecological and evolutionary analyses of bacteria and archaea. The ISME Journal 6: 610.

McFrederick, Q. S., and S. M. Rehan. 2016. Characterization of pollen and bacterial community composition in brood provisions of a small carpenter bee. Molecular Ecology 25: 23022311.

McFrederick, Q. S., H. Q. Vuong, and J. A. Rothman. 2018. Lactobacillus micheneri sp. nov., Lactobacillus timberlakei sp. nov. and Lactobacillus quenuiae sp. nov., lactic acid bacteria isolated from wild bees and flowers. International Journal of Systematic and Evolutionary Microbiology 68: 1879-1884.

McFrederick, Q. S., W. T. Wcislo, D. R. Taylor, H. D. Ishak, S. E. Dowd, and U. G. Mueller. 2012. Environment or kin: whence do bees obtain acidophilic bacteria? Molecular Ecology 21: 1754-1768.

McFrederick, Q. S., J. M. Thomas, J. L. Neff, H. Q. Vuong, K. A. Russell, A. R. Hale, and U. G. Mueller. 2017. Flowers and wild megachilid bees share microbes. Microbial ecology 73: 188-200.

McMurdie, P., and S. Holmes. 2014. Waste not, want not: why rarefying microbiome data is inadmissible PLoS Computational Biology 10: e1003531.

McMurdie, P. J., and S. Holmes. 2013. phyloseq: an R package for reproducible interactive analysis and graphics of microbiome census data. PLoS One 8: e61217.

Mena Granero, A., F. J. Egea Gonzalez, J. M. Guerra Sanz, and J. L. Martínez Vidal. 2005. Analysis of biogenic volatile organic compounds in zucchini flowers: identification of scent sources. Journal of Chemical Ecology 31: 2309-2322.

Metcalf, R., and R. Lampman. 1989. The chemical ecology of Diabroticites and Cucurbitaceae. Experientia 45: 240-247.

Metcalf, R. L., and R. L. Lampman. 1991. Evolution of diabroticite rootworm beetle (Chrysomelidae) receptors for Cucurbita blossom volatiles. Proceedings of the National Academy of Sciences 88: 1869-1872.

Metcalf, R. L., R. A. Metcalf, and A. M. Rhodes. 1980. Cucurbitacins as kairomones for diabroticite beetles. Proceedings of the National Academy of Sciences 77: 3769-3772.

Mitchell, R. F., and L. M. Hanks. 2009. Insect frass as a pathway for transmission of bacterial wilt of cucurbits. Environmental Entomology 38: 395. 
Monaghan, G. W., W. A. Lovis, and K. C. Egan-Bruhy. 2006. Earliest Cucurbita from the Great Lakes, Northern USA. Quaternary Research 65: 216-222.

Moran, N. A. 2003. Tracing the evolution of gene loss in obligate bacterial symbionts. Current Opinion in Microbiology 6: 512-518.

Munroe, D. D., and R. F. Smith. 1980. A revision of the systematics of Acalymma sensu stricto Barber (Coleoptera: Chrysomelidae) from North America including Mexico Memoirs of the Entomological Society of Canada 112: 1-92.

Oliver, K. M., J. Campos, N. A. Moran, and M. S. Hunter. 2008. Population dynamics of defensive symbionts in aphids. Proceedings of the Royal Society B: Biological Sciences 275: 293-299.

Pérez-Jaramillo, J. E., V. J. Carrión, M. Bosse, L. F. Ferrão, M. de Hollander, A. A. Garcia, C. A. Ramírez, R. Mendes, and J. M. Raaijmakers. 2017. Linking rhizosphere microbiome composition of wild and domesticated Phaseolus vulgaris to genotypic and root phenotypic traits. The ISME Journal 11: 2244.

Petersen, J. B., and N. A. Sidell. 1996. Mid-Holocene evidence of Cucurbita sp. from central Maine. American Antiquity 61: 685-698.

Piperno, D. R., and K. E. Stothert. 2003. Phytolith evidence for early Holocene Cucurbita domestication in southwest Ecuador. Science 299: 1054-1057.

Raguso, R. A., and B. A. Roy. 1998. 'Floral' scent production by Puccinia rust fungi that mimic flowers. Molecular Ecology 7: 1127-1136.

Rand, F. V., and E. M. A. Enlows. 1916. Transmission and control of bacterial wilt of cucurbits. Journal of Agricultural Research 6: 7-434.

Rand, F. V., and E. M. A. Enlows. 1920. Bacterial wilt of cucurbits, US Dept. of Agriculture.

Rand, F. V., and L. C. Cash. 1920. Some insect relations of Bacillus tracheiphilus Erw. Sm. Phytopathology 10: 133-140.

Ravoet, J., L. De Smet, I. Meeus, G. Smagghe, T. Wenseleers, and D. C. de Graaf. 2014. Widespread occurrence of honey bee pathogens in solitary bees. Journal of Invertebrate Pathology 122: 55-58.

Rering, C. C., J. J. Beck, G. W. Hall, M. M. McCartney, and R. L. Vannette. 2018. Nectar-inhabiting microorganisms influence nectar volatile composition and attractiveness to a generalist pollinator. New Phytologist 220: 750-759.

SA, A., B. PA, B. HF, and B. AK. 2019. RNA virus spillover from managed honeybees (Apis mellifera) to wild bumblebees (Bombus spp.). PLoS One 14: e0217822.

Salzman, S., M. Whitaker, and N. E. Pierce. 2018. Cycad-feeding insects share a core gut microbiome. Biological Journal of the Linnean Society 123: 728-738.

Samuelson, G. A. 1994. Pollen consumption and digestion by leaf beetles, pp. 179-183, Novel aspects of the biology of Chrysomelidae. Springer.

Sasu, M., I. Seidl-Adams, K. Wall, J. Winsor, and A. Stephenson. 2010a. Floral transmission of Erwinia tracheiphila by cucumber beetles in a wild Cucurbita pepo. Environmental Entomology 39: 140-148.

Sasu, M. A., M. J. Ferrari, and A. G. Stephenson. 2010b. Interrelationships among a virusresistance transgene, herbivory, and a bacterial disease in a wild Cucurbita. International Journal of Plant Sciences 171: 1048-1058. 
Sasu, M. A., M. J. Ferrari, D. Du, J. A. Winsor, and A. G. Stephenson. 2009. Indirect costs of a nontarget pathogen mitigate the direct benefits of a virus-resistant transgene in wild Cucurbita. Proceedings of the National Academy of Sciences 106: 19067-19071.

Shang, Y., Y. Ma, Y. Zhou, H. Zhang, L. Duan, H. Chen, J. Zeng, Q. Zhou, S. Wang, and W. Gu. 2014. Biosynthesis, regulation, and domestication of bitterness in cucumber. Science 346: 1084-1088.

Shapiro, L., C. M. De Moraes, A. G. Stephenson, and M. C. Mescher. 2012. Pathogen effects on vegetative and floral odours mediate vector attraction and host exposure in a complex pathosystem. Ecology Letters 15: 1430-1438.

Shapiro, L., I. Seidl-Adams, C. De Moraes, A. Stephenson, and M. Mescher. 2014. Dynamics of short-and long-term association between a bacterial plant pathogen and its arthropod vector. Scientific Reports 4.

Shapiro, L. R., and K. E. Mauck. 2018. Chemically-mediated Interactions among cucurbits, insects and microbes, pp. 55-90. In J. Tabata (ed.), Chemical Ecology of Insects. CRC Press.

Shapiro, L. R., A. Andrade, E. D. Scully, J. Rocha, J. N. Paulson, and R. Kolter. 2018a. Draft genome sequence of an Erwinia tracheiphila isolate from an infected muskmelon (Cucumis melo). Microbiology Resource Announcements 7: e01058-01018.

Shapiro, L. R., L. Salvaudon, K. E. Mauck, H. Pulido, C. M. De Moraes, A. G. Stephenson, and M. C. Mescher. 2013. Disease interactions in a shared host plant: effects of pre-existing viral infection on cucurbit plant defense responses and resistance to bacterial wilt disease. PLoS One 8: e77393.

Shapiro, L. R., J. N. Paulson, B. J. Arnold, E. D. Scully, O. Zhaxybayeva, N. Pierce, J. Rocha, V. Klepac-Ceraj, K. Holton, and R. Kolter. 2018b. An introduced crop plant is driving diversification of the virulent bacterial pathogen Erwinia tracheiphila. mBio 9: e0130701318.

Shapiro, L. R., E. D. Scully, T. J. Straub, J. Park, A. G. Stephenson, G. A. Beattie, M. L. Gleason, R. Kolter, M. C. Coelho, C. M. D. Moraes, M. C. Mescher, and O. Zhaxybayeva. 2016. Horizontal gene acquisitions, mobile element proliferation, and genome decay in the host-restricted plant pathogen Erwinia tracheiphila. Genome Biology and Evolution 8: 649-664.

Shapiro, L. R., E. D. Scully, D. Roberts, T. J. Straub, S. M. Geib, J. Park, A. G. Stephenson, E. S. Rojas, Q. Liu, G. Beattie, M. Gleason, C. M. D. Moraes, M. C. Mescher, S. J. Fleischer, R. Kolter, N. Pierce, and O. Zhaxybayeva. 2015. Draft genome sequence of Erwinia tracheiphila, an economically important bacterial pathogen of cucurbits. genomeA 3: e00482-00415.

Smith, B. D. 1993. Rivers of change: essays on early agriculture in eastern North America. JSTOR.

Smith, B. D. 1997. The initial domestication of Cucurbita pepo in the Americas 10,000 years ago. Science 276: 932-934.

Smith, B. D. 2006. Eastern North America as an independent center of plant domestication. Proceedings of the National Academy of Sciences 103: 12223-12228.

Smith, E. F. 1920. An introduction to bacterial diseases of plants, W.B. Saunders Company, Philadelphia. 
Tallamy, D. W. 1998. Sequestered cucurbitacins and pathogenicity of Metarhizium anisopliae (Moniliales: Moniliaceae) on spotted cucumber beetle eggs and larvae (Coleoptera: Chrysomelidae). Environmental Entomology 27: 366.

Tallamy, D. W. 1999. An alternate route to insect pharmacophagy: the loose receptor hypothesis. Journal of Chemical Ecology 25: 1987.

Tallamy, D. W., and V. A. Krischik. 1989. Variation and function of cucurbitacins in Cucurbita: an examination of current hypotheses. The American Naturalist 133: 766-786.

Tallamy, D. W., and P. M. Gorski. 1997. Long-and short-term effect of cucurbitacin consumption on Acalymma vittatum (Coleoptera: Chrysomelidae) fitness. Environmental Entomology 26: 672-677.

Tallamy, D. W., J. Stull, N. P. Ehresman, P. M. Gorski, and C. E. Mason. 1997. Cucurbitacins as feeding and oviposition deterrents to insects. Environmental Entomology 26: 678-683.

Team, R. C. 2015. R: A language and environment for statistical computing. R Foundation of Statistical Computing Vienna, Austria.

Vannette, R. L., and T. Fukami. 2016. Nectar microbes can reduce secondary metabolites in nectar and alter effects on nectar consumption by pollinators. Ecology 97: 1410-1419.

Vuong, H. Q., and Q. S. McFrederick. 2019. Comparative genomics of wild bee and flower isolated Lactobacillus reveals potential adaptation to the bee host. Genome Biology and Evolution Accepted Manuscript.

Wang, J., S. H. Chung, M. Peiffer, C. Rosa, K. Hoover, R. Zeng, and G. W. Felton. 2016. Herbivore oral secreted bacteria trigger distinct defense responses in preferred and non-preferred host plants. Journal of Chemical Ecology 42: 463-474.

Whitaker, T. W., and W. P. Bemis. 1964. Evolution in the genus Cucurbita. Evolution 18: 553559.

Whitaker, T. W., and W. Bemis. 1975. Origin and evolution of the cultivated Cucurbita. Bulletin of the Torrey Botanical Club: 362-368.

Wickham, H. 2016. ggplot2: elegant graphics for data analysis, Springer.

Yang, M., G.-C. Deng, Y.-B. Gong, and S.-Q. Huang. Nectar yeasts enhance the interaction between Clematis akebioides and its bumblebee pollinator. Plant Biology 0.

Yao, C., Zehnder, G., Bauske, E., Kloepper, J. 1996. Relationship between cucumber beetle (Coleoptera: Chrysomelidae) density and incidence of bacterial wilt of cucurbits. Journal of Economic Entomology 89: 510-514.

$\mathrm{Yu}, \mathbf{X . ,}$ M. F. Polz, and E. J. Alm. 2019. Interactions in self-assembled microbial communities saturate with diversity. The ISME journal: 1.

Zhou, Y., Y. Ma, J. Zeng, L. Duan, X. Xue, H. Wang, T. Lin, Z. Liu, K. Zeng, and Y. Zhong. 2016. Convergence and divergence of bitterness biosynthesis and regulation in Cucurbitaceae. Nature Plants 2: 16183. 